\title{
STUDIES OF BUNCH ANALYSIS 1 - VARIATION WITHIN AND BETWEEN PALMS
}

\section{CORLEY, R H V*}

\begin{abstract}
There is little information on variation in composition between different bunches from the same palm. In this study, bunch analysis was done on all bunches from three plots of 20 palms, over seven years. There were significant differences between palms for all bunch components. Palm means for oil/bunch were correlated with fruit/bunch and oil/mesocarp, and less strongly with mesocarp/fruit. A previously unreported correlation between palm means for fruit/bunch and oil/dry mesocarp was found; this appeared to be a genetic effect, as there was no such correlation within palms. There was also a correlation between palm means for fresh fruit bunch (FFB) yield and oil/dry mesocarp. Between bunches within palms, the most variable bunch component was fruit/bunch; for this and for oil/mesocarp the within-palm component of variance was much larger than the between-palms component. For fruit composition (mesocarp, kernel and shell/fruit), the between-palm variance was larger. Within palms, mesocarp/fruit tended to be negatively correlated with fruit/bunch. Shell/fruit was significantly correlated with kernel/fruit in most tenera palms, but not in most duras.
\end{abstract}

\section{Keywords: oil/bunch, kernel/bunch, variability.}

Date received: 22 May 2017; Sent for revision: 14 June 2017; Received in final form: 9 August 2017; Accepted: 4 April 2018.

\section{INTRODUCTION}

Bunch analysis to determine oil content is an important part of most oil palm field research. The Nigerian Institute for Oil Palm Research (NIFOR) method of bunch analysis (Blaak et al., 1963) is almost universally used. The accuracy and precision of this method was studied extensively in Malaysia in the 1980s. Rao et al. (1983) found that accuracy was laboratory dependent; for comparison of treatments within a programme this does not matter too much, as errors appear to be systematic. Precision might be questioned because there are several successive sampling stages in the analysis: the end result is that a bunch weighing perhaps $20 \mathrm{~kg}$ is represented by a

Highlands, New Road, Great Barford, Bedford MK44 3LQ, United Kingdom.

E-mail: herewardc@aol.com
$5 \mathrm{~g}$ sample of dry mesocarp for oil extraction. Few comparisons of estimates based on this method with actual total oil have been published. Chan et al. (1999) obtained a correlation of 0.99 between estimated and true values of tenera oil/bunch $(\mathrm{O} / \mathrm{B})$, but they only analysed five bunches (and one dura bunch), and did not use the standard NIFOR method for analysis. Hor et al. (1998) used the standard method, with repeated sampling of spikelets and fruit so that the whole bunch was used. For 30 bunches (fruit form not specified) they obtained a correlation of 0.982 between single samples and $\mathrm{O} / \mathrm{B}$ of the entire bunch. Lim and Toh (1984) compared estimates from the standard method for kernel/bunch $(\mathrm{K} / \mathrm{B})$ with true $\mathrm{K} / \mathrm{B}$, by extracting and weighing all kernels. For 100 bunches, they obtained a correlation of 0.99 , indicating very good precision for the estimate. $\mathrm{O} / \mathrm{B}$ requires one more sampling stage than $\mathrm{K} / \mathrm{B}$, but it is a reasonable assumption that $\mathrm{O} / \mathrm{B}$ estimates also have high precision. 
The NIFOR method gives a good estimate of the oil content of a bunch, therefore, but it is too laborious to allow all bunches from a trial to be analysed, so to estimate the oil yield of a palm or plot a sample of bunches must be taken. For a given level of precision, the required sample size will depend on the variation between bunches, but there is very little information on this.

In this article, I have looked at variation in bunch composition, using data from three small plots of 20 commercial DxP palms, from which all bunches were put through standard bunch analysis. Other data from these palms were studied by Breure and Corley (1992) and Corley (1977). In part 2 of this study, the effects of bunch sample size and sampling methods on the precision of $\mathrm{O} / \mathrm{B}$ and oil yield estimates will be investigated.

\section{MATERIAL AND METHODS}

Three plots of 20 palms were chosen at random from commercial fields on Ulu Remis Estate, in Johor, Malaysia (approximately $1^{\circ} 51^{\prime} \mathrm{N}, 103^{\circ}$ $28^{\prime} \mathrm{E}$ ), and yields were recorded over a period of seven years four months, from September 1968 to December 1975. Details of the three plots are given in Table 1. The 1958 planting was one of the first commercial DxP plantings in Malaysia (probably Deli x Yangambi). All the material was nominally DxP, but before the introduction of DxP crosses there was no marker for assessing contamination (Corley, 2005); standards of pollination were poor, with high dura incidence in the 1958 and 1960 plots (Table 1). It appears that, when the 1958 planting started fruiting, the problem of contamination was recognised, pollination methods were improved, and the 1963 plot was 100\% tenera. The fact that the majority of palms in Plots A and B were illegitimate duras (probably with a Deli male parent, so pure Deli dura) will not affect within-palm variation, the main subject of this study. I have combined data from the teneras in the 1958 and 1960 plantings; there were thus two groups of duras and two groups of teneras.

Bunches were harvested at the estate ripeness standard, but the number of detached fruit per bunch was not recorded. All bunches were weighed, and analysed by the standard NIFOR bunch analysis method (Blaak et al., 1963). A few bunches (Plot A: 18 bunches; Plot B: 20; Plot C: 12) were not completely analysed due to laboratory errors; these were excluded from all subsequent analysis.

The bunch analysis data were used to study variability in bunch composition, both between and within palms. Within and between palm variance components were calculated, to give an estimate of broad-sense heritability (Falconer, 1981). In the $A+B$ tenera group, the plot component was removed from the between palm variance. Correlations between bunch components were also calculated. Where the same correlation is calculated for many different data sets, some apparently significant values are likely to arise by chance, and it is appropriate to apply the Bonferroni correction to the significance level (Bonferroni, 1936). To give an overall significance level of $P$, individual correlations are

TABLE 1. DETAILS OF THE PLOTS STUDIED

(all bunch components in percent)

\begin{tabular}{|c|c|c|c|c|c|c|c|c|c|c|c|c|c|c|c|}
\hline \multirow{4}{*}{$\begin{array}{l}\text { Plot } \\
\text { Year of planting } \\
\text { Fruit form }\end{array}$} & \multicolumn{6}{|l|}{$\mathbf{A}$} & \multicolumn{6}{|l|}{ B } & \multicolumn{3}{|l|}{$\mathrm{C}$} \\
\hline & \multicolumn{6}{|l|}{1958} & \multicolumn{6}{|l|}{1960} & \multicolumn{3}{|l|}{1963} \\
\hline & Dura & & & Tenera & & & Dura & & & Tenera & & & Tenera & & \\
\hline & Mean & $\mathrm{SD}^{\mathrm{a}}$ & $\mathrm{CV}$ & Mean & SD & $\mathrm{CV}$ & Mean & SD & $\mathrm{CV}$ & Mean & SD & $\mathrm{CV}$ & Mean & SD & $\mathrm{CV}$ \\
\hline Number of palms & 13 & & & 7 & & & 17 & & & 3 & & & 20 & & \\
\hline Bunches analysed & 609 & & & 427 & & & 1164 & & & 193 & & & 1635 & & \\
\hline FFB (kg/palm.yr) & 145 & 16.3 & 11.2 & 183 & 22.8 & 12.5 & 157 & 29.8 & 19.0 & 171 & 27.8 & 16.3 & 159 & 27.1 & 17.1 \\
\hline Bunch No./palm.yr & 6.4 & 1.16 & 18.1 & 8.3 & 0.93 & 11.2 & 9.3 & 2.38 & 25.4 & 8.8 & 2.40 & 27.4 & 11.1 & 3.75 & 33.7 \\
\hline Mean bunch wt (kg) & 23.3 & 3.83 & 16.4 & 22.1 & 2.47 & 11.2 & 17.3 & 2.56 & 14.8 & 20.1 & 2.15 & 10.7 & 15.2 & 3.30 & 21.7 \\
\hline Oil yield (kg/p.yr) & 27.3 & 4.58 & 16.8 & 41.6 & 7.15 & 17.2 & 28.5 & 6.67 & 23.4 & 44.4 & 8.62 & 19.4 & 38.7 & 7.41 & 19.2 \\
\hline Fruit/bunch & 65.0 & 2.87 & 4.4 & 62.1 & 2.11 & 3.4 & 65.5 & 3.77 & 5.8 & 62.7 & 1.61 & 2.6 & 66.1 & 4.21 & 6.4 \\
\hline Mesocarp/fruit & 59.5 & 3.51 & 5.9 & 77.3 & 3.58 & 4.6 & 60.9 & 2.33 & 3.8 & 82.9 & 4.09 & 4.9 & 77.9 & 2.70 & 3.5 \\
\hline Dry matter/mesocarp & 64.2 & 3.43 & 5.3 & 62.7 & 2.11 & 3.4 & 60.7 & 2.13 & 3.5 & 65.3 & 0.47 & 0.7 & 63.0 & 1.79 & 2.8 \\
\hline Oil.dry mesocarp & 75.0 & 1.93 & 2.6 & 75.5 & 1.79 & 2.4 & 74.3 & 1.48 & 2.0 & 76.0 & 0.29 & 0.4 & 74.4 & 1.59 & 2.1 \\
\hline Oil/fresh mesocarp & 48.2 & 3.36 & 7.0 & 47.3 & 1.71 & 3.6 & 45.2 & 2.11 & 4.7 & 49.7 & 0.52 & 1.1 & 47.0 & 2.00 & 4.3 \\
\hline Oil/bunch & 18.5 & 1.63 & 8.8 & 22.7 & 1.96 & 8.6 & 17.9 & 1.57 & 8.8 & 25.7 & 0.83 & 3.2 & 24.1 & 2.17 & 9.0 \\
\hline Kernel/fruit & 8.8 & 1.85 & 21.0 & 9.8 & 2.40 & 24.5 & 8.0 & 1.01 & 12.7 & 8.3 & 2.89 & 34.6 & 9.4 & 1.44 & 15.4 \\
\hline Shell/fruit & 31.7 & 2.03 & 6.4 & 12.9 & 1.69 & 13.1 & 31.2 & 2.17 & 6.9 & 8.7 & 1.66 & 19.1 & 12.8 & 1.83 & 14.3 \\
\hline Kernel/bunch & 5.7 & 1.22 & 21.2 & 6.1 & 1.37 & 22.6 & 5.2 & 0.77 & 14.7 & 5.3 & 1.93 & 36.5 & 6.2 & 1.17 & 18.7 \\
\hline
\end{tabular}

Note: a Standard deviations of palm means.

$\mathrm{CV}$ - coefficient of variation.

FFB - fresh fruit bunch. 
tested at a probability of $\mathrm{P} / \mathrm{n}$, where $n$ is the number of repetitions of the comparison. With a total of 60 palms, the appropriate significance level for testing within-palm correlations between bunch components is $\mathrm{P}=0.05 / 60=0.000833$.

Additional data came from extensive bunch analysis of three clones (details given by Corley and Law, 2001).

\section{RESULTS AND DISCUSSION}

\section{Variation between Palms}

Table 1 shows overall yields of the plots. The 20 palms in Plot C gave a mean oil yield of $38.7 \mathrm{~kg} /$ palm. yr, equivalent to $5.35 \mathrm{t} / \mathrm{ha}$. yr at 138 palms ha- $^{-1}$ for the teneras in Plots A and B the mean oil yield was $42.4 \mathrm{~kg} /$ palm. yr, equivalent to $5.85 \mathrm{t} / \mathrm{ha}$. yr.

The first point to ascertain was whether there were differences between palms in bunch composition. Within each plot, one-way analysis of variance showed very highly significant differences $(P<0.001)$ between palms for mean bunch weight and for all components of the bunch (data not shown). Within plots there was little difference between bunch components in coefficient of variation $(\mathrm{CV})$, but $\mathrm{O} / \mathrm{B}$ had $\mathrm{CV}$ larger than the individual components of $\mathrm{O} / \mathrm{B}$ in all plots (Table 1).

Tables 2 to 5 show that $\mathrm{O} / \mathrm{B}$ was positively correlated with fruit/bunch (F/B) and oil/fresh mesocarp $(\mathrm{O} / \mathrm{WM})$ in all groups of palms, significantly so in three groups. $\mathrm{O} / \mathrm{WM}$ is the product of dry matter in mesocarp (D/WM) and oil/dry mesocarp (O/DM), and O/B was positively correlated with both these components. With O/DM, the correlation was significant in all four groups. Correlations with mesocarp/fruit $(\mathrm{M} / \mathrm{F})$ were positive, but only significant in $\mathrm{A}+\mathrm{B}$ teneras. Thus, it appears that palm-to-palm variation in $\mathrm{O} / \mathrm{B}$ depended more on variation in $\mathrm{F} / \mathrm{B}$ and $\mathrm{O} / \mathrm{WM}$ than on variation in $\mathrm{M} / \mathrm{F}$ in these groups of palms.

The correlations of $\mathrm{O} / \mathrm{B}$ with kernel/fruit $(\mathrm{K} / \mathrm{F})$ and shell/fruit (S/F) were significant and negative in $\mathrm{A}+\mathrm{B}$ teneras. In the other groups correlations between $\mathrm{O} / \mathrm{B}$ and $\mathrm{K} / \mathrm{F}$ were weak, but $\mathrm{S} / \mathrm{F}$ was consistently negatively correlated with $\mathrm{O} / \mathrm{B}$. Kernel/fruit and S/F were positively correlated in three groups, reflecting the fact that the shell encloses the kernel. Correlations between $\mathrm{K} / \mathrm{F}$ and $\mathrm{K} / \mathrm{B}$ were higher than between $\mathrm{F} / \mathrm{B}$ and $\mathrm{K} / \mathrm{B}$; this contrasts with $\mathrm{O} / \mathrm{B}$, where correlations with $\mathrm{F} / \mathrm{B}$ were generally higher than with $\mathrm{M} / \mathrm{F}$ (see above). Although in two groups $\mathrm{O} / \mathrm{B}$ and $\mathrm{K} / \mathrm{B}$ both showed high correlations with $\mathrm{F} / \mathrm{B}$, there were no significant correlations of $\mathrm{O} / \mathrm{B}$ and $\mathrm{K} / \mathrm{B}$.

Fruit/bunch was positively correlated with O/DM, significantly so in three groups. Such a correlation has not been reported before, but a similar significant positive correlation has been found in a population of 955 Deli $x$ AVROS palms in a genomic selection study (Teh, C K, pers. comm., 2017). Jeenor and Volkaert (2014) found closely linked quantitative trait linkage (QTL) for F/B and oil/fruit ratio $(\mathrm{M} / \mathrm{F} \times \mathrm{O} / \mathrm{WM})$, the latter close to the gene for phosphatidate phosphatase, which

TABLE 2. CORRELATIONS BETWEEN PALM MEANS FOR BUNCH COMPONENTS PLOT A DURAS (all with 11 degrees of freedom)

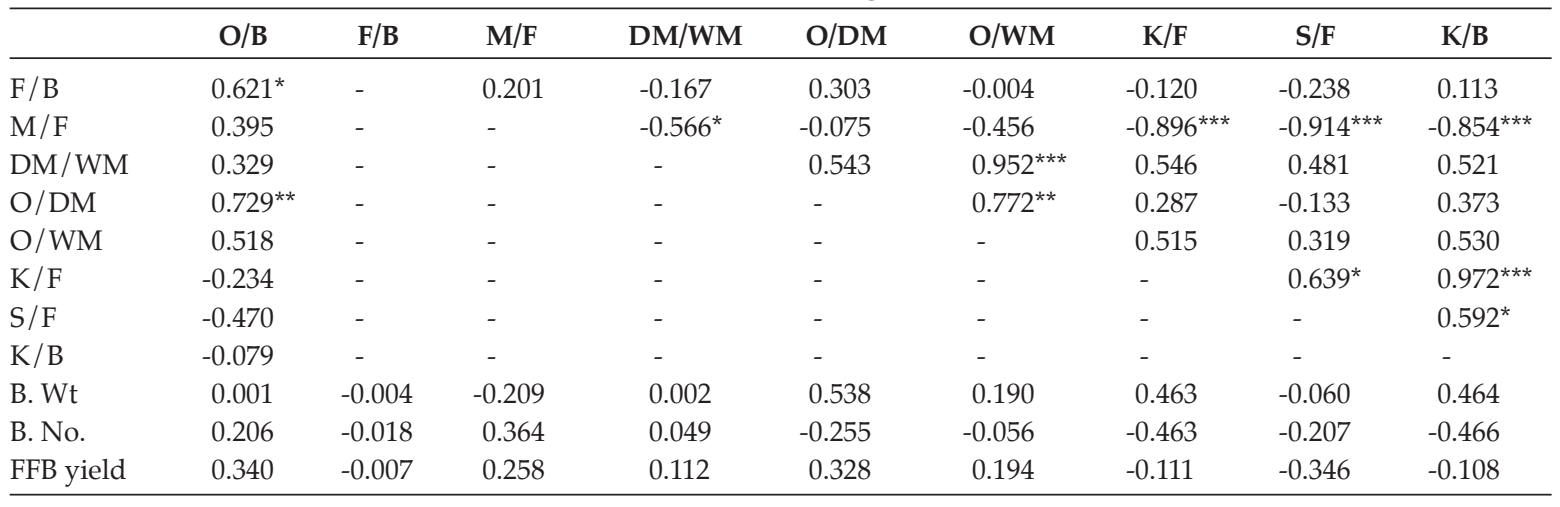

Note: $\quad$ *Significant at $\mathrm{P}<0.05, \quad$ ** Significant at $\mathrm{P}<0.01, \quad{ }^{* *}$ Significant at $\mathrm{P}<0.001$.

$\mathrm{O} / \mathrm{B}$ - oil/bunch

F/B - fruit/bunch.

$\mathrm{M} / \mathrm{F}$ - mesocarp/fruit.

$\mathrm{DM} / \mathrm{WM}$ - dry matter content of fresh mesocarp.

O/DM - oil/dry mesocarp.

$\mathrm{O} / \mathrm{WM}$ - oil/fresh mesocarp.

$\mathrm{K} / \mathrm{F}$ - kernel/fruit.

$\mathrm{S} / \mathrm{F}$ - shell/fruit.

K/B - kernel/bunch.

FFB - fruih fruit bunch. 
TABLE 3. CORRELATIONS BETWEEN PALM MEANS FOR BUNCH COMPONENTS, PLOT B DURAS (all with 15 degrees of freedom)

\begin{tabular}{|c|c|c|c|c|c|c|c|c|c|}
\hline & O/B & F/B & $\mathbf{M} / \mathbf{F}$ & DM/WM & O/DM & O/WM & $\mathrm{K} / \mathrm{F}$ & $S / F$ & K/B \\
\hline $\mathrm{M} / \mathrm{F}$ & 0.202 & - & - & 0.033 & -0.118 & -0.034 & -0.363 & $-0.901^{* * *}$ & -0.425 \\
\hline $\mathrm{O} / \mathrm{DM}$ & $0.704^{* *}$ & - & - & - & - & $0.741^{\star * *}$ & -0.229 & 0.235 & 0.006 \\
\hline $\mathrm{O} / \mathrm{WM}$ & $0.785^{\star * *}$ & - & - & - & - & - & 0.147 & -0.030 & 0.273 \\
\hline $\mathrm{K} / \mathrm{B}$ & 0.299 & - & - & - & - & - & - & - & - \\
\hline B. Wt & -0.118 & -0.259 & 0.030 & 0.148 & -0.122 & 0.069 & 0.457 & -0.242 & 0.305 \\
\hline B. No. & 0.388 & 0.413 & -0.034 & 0.050 & $0.535^{\star}$ & 0.256 & $-0.504^{*}$ & 0.274 & -0.270 \\
\hline FFB yield & 0.389 & 0.270 & 0.020 & 0.176 & $0.618^{* *}$ & 0.392 & -0.355 & 0.151 & -0.190 \\
\hline
\end{tabular}

Note: ${ }^{*}$ Significant at $\mathrm{P}<0.05,{ }^{* *}$ Significant at $\mathrm{P}<0.01,{ }^{* *}$ Significant at $\mathrm{P}<0.001$.

$\mathrm{F} / \mathrm{B}$ - fruit/bunch.

$\mathrm{M} / \mathrm{F}$ - mesocarp/fruit.

$\mathrm{DM} / \mathrm{WM}$ - dry matter content of fresh mesocarp.

$\mathrm{O} / \mathrm{DM}$ - oil/dry mesocarp.

$\mathrm{O} / \mathrm{WM}$ - oil/ fresh mesocarp.

$\mathrm{K} / \mathrm{F}$ - kernel/ fruit.

$\mathrm{S} / \mathrm{F}$ - shell/ fruit.

$\mathrm{K} / \mathrm{B}$ - kernel/bunch.

FFB - fruih fruit bunch.

TABLE 4. CORRELATIONS BETWEEN PALM MEANS FOR BUNCH COMPONENTS, PLOTS A AND B TENERAS (all with eight degrees of freedom)

\begin{tabular}{|c|c|c|c|c|c|c|c|c|c|}
\hline & $\mathrm{O} / \mathrm{B}$ & F/B & $\mathrm{M} / \mathrm{F}$ & DM/WM & O/DM & O/WM & $K / F$ & $\mathrm{~S} / \mathrm{F}$ & $\mathrm{K} / \mathrm{B}$ \\
\hline $\mathrm{M} / \mathrm{F}$ & $0.842^{* *}$ & - & - & 0.209 & 0.616 & 0.464 & $-0.878^{* * *}$ & $-0.856^{* * *}$ & $-0.860^{\star * *}$ \\
\hline $\mathrm{O} / \mathrm{DM}$ & $0.692^{*}$ & - & - & - & - & 0.578 & -0.615 & -0.368 & -0.534 \\
\hline $\mathrm{O} / \mathrm{WM}$ & $0.788^{* *}$ & - & - & - & - & - & -0.276 & $-0.646^{*}$ & -0.211 \\
\hline $\mathrm{K} / \mathrm{B}$ & -0.578 & - & - & - & - & - & - & - & - \\
\hline B. Wt & -0.419 & -0.354 & -0.312 & -0.258 & -0.443 & -0.449 & 0.226 & 0.245 & 0.177 \\
\hline B. No. & 0.528 & 0.235 & $0.650^{*}$ & 0.055 & 0.602 & 0.300 & -0.511 & 0.480 & -0.490 \\
\hline FFB yield & 0.145 & 0.027 & 0.464 & -0.214 & 0.405 & -0.019 & -0.398 & -0.300 & -0.406 \\
\hline
\end{tabular}

Note: ${ }^{*}$ Significant at $\mathrm{P}<0.05,{ }^{* *}$ Significant at $\mathrm{P}<0.01,{ }^{* *}$ Significant at $\mathrm{P}<0.001$.

$\mathrm{F} / \mathrm{B}$ - fruit/bunch.

$\mathrm{M} / \mathrm{F}$ - mesocarp/ fruit.

$\mathrm{DM} / \mathrm{WM}$ - dry matter content of fresh mesocarp.

$\mathrm{O} / \mathrm{DM}$ - oil/dry mesocarp.

$\mathrm{O} / \mathrm{WM}$ - oil/ fresh mesocarp.

$\mathrm{K} / \mathrm{F}$ - kernel/ fruit.

$\mathrm{S} / \mathrm{F}$ - shell/ fruit.

K/B - kernel/bunch.

FFB - fruih fruit bunch.

is involved in triglyceride synthesis. However, the correlation between $\mathrm{F} / \mathrm{B}$ and oil/fruit was weak and negative. Seng et al. (2016) found a weak nega tive correlation between $\mathrm{F} / \mathrm{B}$ and $\mathrm{O} / \mathrm{DM}$, with no linked QTL. Thus, the relationship between F/B and oil/mesocarp needs further investigation.

Given that oil palm yield is generally considered to be source-limited (Corley and Tinker, 2016), and that oil has a higher energy content than other bunch components, one might expect a negative correlation between fresh fruit bunch (FFB) yield and $\mathrm{O} / \mathrm{B}$ for individual palms. A low but significant negative correlation between $\mathrm{O} / \mathrm{B}$ and FFB yield was found in the population of 955 palms mentioned above (Teh, C K, pers. comm., 2017), but in the groups studied here there were no significant correlations between $\mathrm{O} / \mathrm{B}$ and FFB yield. In three groups, there was a positive correlation 
TABLE 5. CORRELATIONS BETWEEN PALM MEANS FOR BUNCH COMPONENTS, PLOT C TENERAS (all with 18 degrees of freedom)

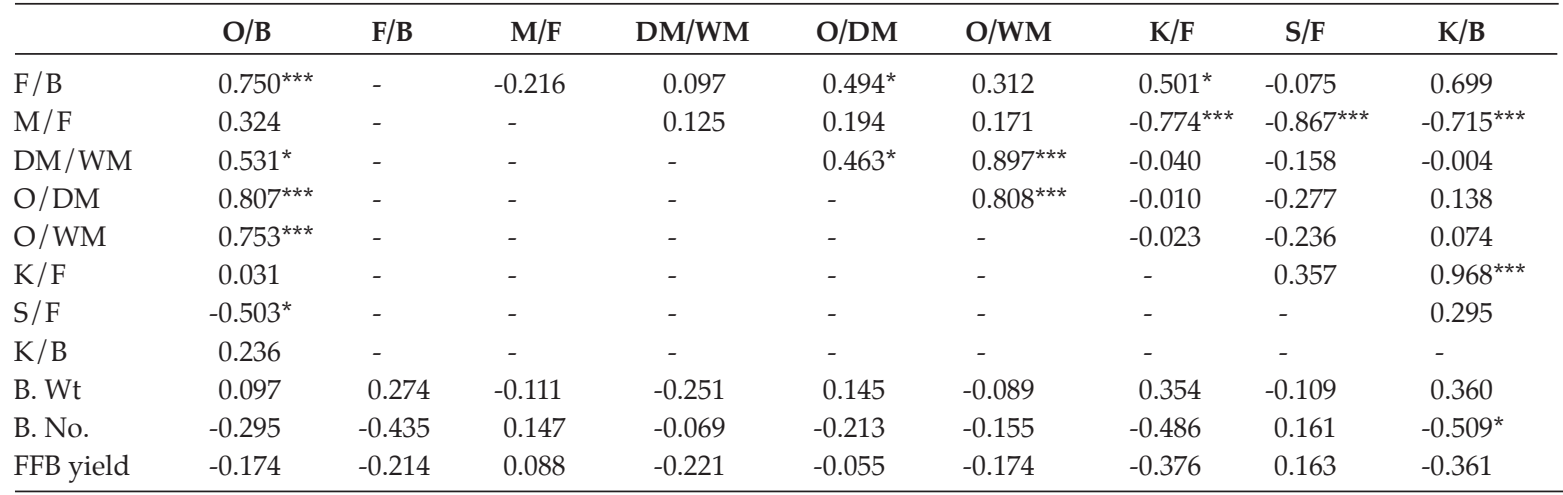

Note: ${ }^{*}$ Significant at $\mathrm{P}<0.05,{ }^{* *}$ Significant at $\mathrm{P}<0.01,{ }^{* * *}$ Significant at $\mathrm{P}<0.001$

$\mathrm{O} / \mathrm{B}$ - oil/bunch

$\mathrm{F} / \mathrm{B}$ - fruit/bunch.

$\mathrm{M} / \mathrm{F}$ - mesocarp/fruit.

DM/WM - dry matter content of fresh mesocarp.

$\mathrm{O} / \mathrm{DM}$ - oil/dry mesocarp.

$\mathrm{O} / \mathrm{WM}$ - oil/ fresh mesocarp.

$\mathrm{K} / \mathrm{F}$ - kernel/fruit.

$\mathrm{S} / \mathrm{F}$ - shell / fruit.

$\mathrm{K} / \mathrm{B}$ - kernel/bunch.

FFB - fruih fruit bunch.

between FFB yield and O/DM, significant in one group. This does not appear to be a consequence of the correlation between $\mathrm{F} / \mathrm{B}$ and $\mathrm{O} / \mathrm{DM}$, as FFB yield and F/B were not correlated. These results, and Teh's study (Teh, C K, pers. comm., 2017), suggest the possibility that FFB yield and $\mathrm{O} / \mathrm{DM}$ are not completely independently inherited.

There were no significant negative correlations between mean bunch weight and $\mathrm{O} / \mathrm{B}$, so it is likely that the negative correlation observed by Sharma et al. (1999) was an effect of palm age, rather than of bunch size per se. There were also no significant correlations between $\mathrm{O} / \mathrm{B}$ and bunch number per palm, though M/F was significantly correlated with bunch number in one group.

In all groups, $\mathrm{K} / \mathrm{F}$ and $\mathrm{K} / \mathrm{B}$ were negatively correlated with bunch number, each being significant in one group. Such correlations have not been noted in other studies.

\section{Variation within Palms}

In Table 6, means and standard deviations for bunches from individual palms are summarised for all bunch components. In all groups, F/B, which depends on pollination efficiency, was the most variable component of $\mathrm{O} / \mathrm{B}$, followed by $\mathrm{O} / \mathrm{WM}$. The data from these plots were all collected before the introduction of Elaeidobius kamerunicus to Malaysia, so it appeared possible that poor pollination by Thrips hawaiiensis might have contributed to the variability in F/B. However, Table 7 shows that for bunches of three clones analysed in 1983, after the introduction of the weevil, F/B was still the most variable $\mathrm{O} / \mathrm{B}$ component. The results in Table 6 therefore appear relevant to present-day bunch analysis with pollination by E. kamerunicus.

Oil to fresh mesocarp is expected to vary with ripeness, but harvesting was done at a five to seven-day interval with a fixed ripeness standard, so variation due to ripeness differences could not practicably be reduced much further. Table 7 shows that for three clones at four different degrees of ripeness, $\mathrm{O} / \mathrm{WM}$ remained the second most variable component after F/B. Although mean O/B increases with loose fruit number, control of ripeness standard does not appear to reduce the $\mathrm{CV}$ of $\mathrm{O} / \mathrm{B}$.

Table 8 shows correlations between bunch components within palms. For every pair of bunch components, there is at least one palm showing a significant correlation. A number of these correlations are probably spurious; there are several examples of both negative and positive correlations for the same components. It may be that the Bonferroni correction, as applied here, is not sufficiently stringent to rule out all spurious correlations, but it is also possible that errors in bunch analysis or in data transcription are a factor.

Many of the within-palm correlations are expected: $\mathrm{O} / \mathrm{B}$ is the product of $\mathrm{F} / \mathrm{B}, \mathrm{M} / \mathrm{F}$ and $\mathrm{O} / \mathrm{WM}$, and is significantly correlated with $\mathrm{F} / \mathrm{B}$ and $\mathrm{O} / \mathrm{WM}$ in most palms. For F/B, the correlations were significant at $5 \%$ for all but five palms out of 60 , and for $\mathrm{O} / \mathrm{WM}$ for all but three palms. The correlations between $\mathrm{M} / \mathrm{F}$ and $\mathrm{O} / \mathrm{B}$ were lower (significant for only 25 palms out of 60 ), indicating 
TABLE 6. MEANS, STANDARD DEVIATIONS AND COEFFICIENTS OF VARIATION FOR BUNCH COMPONENTS WITHIN PALMS (averages of means, SD and CV for bunches from individual palms)

\begin{tabular}{|c|c|c|c|c|c|c|c|c|c|c|c|c|}
\hline \multirow{4}{*}{$\begin{array}{l}\text { Component } \\
\text { No. of bunches analysed } \\
\text { Bunches/palm (mean, range) }\end{array}$} & \multicolumn{3}{|c|}{ Plot $\mathrm{A}$, dura } & \multicolumn{3}{|c|}{ Plot B, dura } & \multicolumn{3}{|c|}{ Plots A+B, tenera } & \multicolumn{3}{|c|}{ Plot $\mathrm{C}$, tenera } \\
\hline & \multicolumn{3}{|l|}{609} & \multicolumn{3}{|l|}{1164} & \multicolumn{3}{|l|}{620} & \multicolumn{3}{|l|}{1643} \\
\hline & 47 & \multicolumn{2}{|c|}{$36-63$} & \multirow{2}{*}{68} & \multicolumn{2}{|c|}{$41-96$} & \multirow{2}{*}{$\frac{62}{\text { Mean }}$} & \multicolumn{2}{|c|}{$47-89$} & \multirow{2}{*}{$\frac{82}{\text { Mean }}$} & \multicolumn{2}{|c|}{$48-169$} \\
\hline & Mean & SD & $\mathrm{CV}$ & & SD & $\mathrm{CV}$ & & SD & $\mathrm{CV}$ & & SD & $\mathrm{CV}$ \\
\hline Fruit/bunch & 65.0 & 6.2 & 9.6 & 65.5 & 7.6 & 11.7 & 62.3 & 6.8 & 10.9 & 66.1 & 7.2 & 11.0 \\
\hline Mesocarp/fruit & 59.5 & 2.5 & 4.2 & 60.9 & 2.8 & 4.6 & 79.0 & 2.8 & 3.6 & 77.9 & 2.9 & 3.7 \\
\hline Dry matter/mesocarp & 64.2 & 4.0 & 6.2 & 60.7 & 4.7 & 7.8 & 63.5 & 3.8 & 6.0 & 63.1 & 4.5 & 7.2 \\
\hline Oil/dry mesocarp & 75.0 & 2.1 & 2.8 & 74.3 & 2.3 & 3.1 & 75.7 & 1.9 & 2.5 & 74.4 & 2.3 & 3.1 \\
\hline Oil/fresh mesocarp & 48.2 & 3.6 & 7.5 & 45.2 & 4.3 & 9.5 & 48.0 & 3.9 & 8.2 & 47.0 & 4.2 & 9.0 \\
\hline Oil/bunch & 18.1 & 2.5 & 13.5 & 17.9 & 2.8 & 15.7 & 23.6 & 3.3 & 14.1 & 24.1 & 3.5 & 14.7 \\
\hline Kernel/fruit & 8.8 & 1.3 & 14.3 & 8.0 & 1.3 & 16.8 & 9.3 & 1.6 & 17.7 & 9.4 & 1.6 & 17.1 \\
\hline Shell / fruit & 31.7 & 2.2 & 6.8 & 31.2 & 2.2 & 7.1 & 11.6 & 1.6 & 13.4 & 12.8 & 1.7 & 13.5 \\
\hline Kernel/bunch & 5.7 & 1.1 & 18.4 & 5.2 & 1.1 & 22.1 & 5.8 & 1.3 & 22.4 & 6.2 & 1.4 & 22.8 \\
\hline
\end{tabular}

Note: SD - standard deviations.

$\mathrm{CV}$ - coefficient of variation.

TABLE 7. MEANS, STANDARD DEVIATIONS AND COEFFICIENTS OF VARIATION FOR BUNCH COMPONENTS FOR THREE CLONES IN 1983, GROUPED BY NUMBER OF LOOSE FRUIT (LF) PER BUNCH

\begin{tabular}{|c|c|c|c|c|c|c|c|c|c|c|c|c|c|c|}
\hline \multirow[t]{2}{*}{ Component } & \multirow{2}{*}{$\begin{array}{l}\text { LF No./ } \\
\text { bunch }\end{array}$} & \multicolumn{4}{|c|}{ Clone 926} & \multicolumn{5}{|c|}{ Clone 975} & \multicolumn{3}{|c|}{ Clone 997} & \multirow{2}{*}{$\begin{array}{l}\text { Mean } \\
\text { CV }\end{array}$} \\
\hline & & $\mathbf{n}$ & Mean & SD & $\mathrm{CV}$ & $\mathbf{n}$ & Mean & SD & $\mathrm{CV}$ & $\mathbf{n}$ & Mean & SD & $\mathrm{CV}$ & \\
\hline \multirow[t]{4}{*}{$\mathrm{F} / \mathrm{B}$} & $1-10$ & 44 & 60.2 & 6.9 & 11.4 & 32 & 63.0 & 9.8 & 15.6 & 66 & 59.2 & 7.0 & 11.9 & 13.0 \\
\hline & $11-25$ & 41 & 60.4 & 10.1 & 16.8 & 22 & 61.2 & 9.5 & 15.5 & 60 & 62.1 & 3.2 & 5.1 & 12.4 \\
\hline & $26-50$ & 39 & 59.5 & 9.7 & 16.2 & 27 & 60.1 & 13.9 & 23.2 & 51 & 61.7 & 5.2 & 8.5 & 16.0 \\
\hline & $51-75$ & 24 & 64.0 & 6.7 & 10.5 & 20 & 60.8 & 11.4 & 18.8 & 51 & 61.6 & 4.8 & 7.9 & 12.4 \\
\hline \multirow[t]{4}{*}{$\mathrm{M} / \mathrm{F}$} & $1-10$ & 44 & 85.6 & 3.8 & 4.5 & 32 & 73.1 & 4.3 & 5.9 & 66 & 86.8 & 2.4 & 2.7 & 4.4 \\
\hline & $11-25$ & 41 & 85.4 & 3.8 & 4.4 & 22 & 72.5 & 4.2 & 5.8 & 60 & 86.3 & 3.1 & 3.5 & 4.6 \\
\hline & $26-50$ & 39 & 86.6 & 3.6 & 4.1 & 27 & 74.0 & 5.7 & 7.7 & 51 & 87.7 & 2.3 & 2.6 & 4.8 \\
\hline & $51-75$ & 24 & 85.5 & 3.0 & 3.5 & 20 & 72.6 & 4.9 & 6.7 & 51 & 87.7 & 2.3 & 2.6 & 4.3 \\
\hline \multirow[t]{4}{*}{$\mathrm{DM} / \mathrm{WM}$} & $1-10$ & 44 & 63.8 & 5.6 & 8.8 & 32 & 65.0 & 4.0 & 6.1 & 66 & 68.6 & 3.8 & 5.5 & 6.8 \\
\hline & $11-25$ & 41 & 65.2 & 4.5 & 6.8 & 22 & 65.1 & 6.7 & 10.2 & 60 & 69.8 & 3.4 & 4.9 & 7.3 \\
\hline & $26-50$ & 39 & 66.4 & 4.1 & 6.1 & 27 & 65.1 & 6.4 & 9.7 & 51 & 70.4 & 3.8 & 5.5 & 7.1 \\
\hline & $51-75$ & 24 & 67.8 & 3.4 & 5.0 & 20 & 67.6 & 7.0 & 10.3 & 51 & 70.7 & 4.1 & 5.8 & 7.0 \\
\hline \multirow[t]{4}{*}{$\mathrm{O} / \mathrm{DM}$} & $1-10$ & 44 & 69.7 & 2.9 & 4.2 & 32 & 67.8 & 5.5 & 8.8 & 66 & 70.9 & 5.2 & 7.4 & 6.8 \\
\hline & $11-25$ & 41 & 70.7 & 2.8 & 4.1 & 22 & 67.2 & 6.7 & 9.9 & 60 & 72.8 & 4.5 & 6.2 & 6.7 \\
\hline & $26-50$ & 39 & 71.4 & 2.7 & 3.7 & 27 & 68.0 & 4.9 & 7.1 & 51 & 72.2 & 5.2 & 7.2 & 6.0 \\
\hline & $51-75$ & 24 & 71.8 & 2.9 & 4.0 & 20 & 69.1 & 4.4 & 6.3 & 51 & 72.7 & 5.3 & 7.3 & 5.7 \\
\hline \multirow[t]{4}{*}{$\mathrm{O} / \mathrm{WM}$} & $1-10$ & 44 & 44.5 & 4.5 & 10.1 & 32 & 44.1 & 4.6 & 10.4 & 66 & 48.6 & 4.1 & 8.5 & 9.7 \\
\hline & $11-25$ & 41 & 46.1 & 4.1 & 8.9 & 22 & 43.6 & 5.0 & 11.5 & 60 & 50.9 & 4.1 & 8.0 & 9.5 \\
\hline & $26-50$ & 39 & 47.4 & 3.2 & 6.7 & 27 & 44.3 & 5.5 & 12.5 & 51 & 50.8 & 4.2 & 8.2 & 9.1 \\
\hline & $51-75$ & 24 & 48.7 & 2.7 & 5.6 & 20 & 46.9 & 6.6 & 14.0 & 51 & 51.4 & 4.6 & 9.0 & 9.5 \\
\hline \multirow[t]{4}{*}{$\mathrm{O} / \mathrm{B}$} & $1-10$ & 44 & 22.9 & 3.5 & 15.5 & 32 & 20.5 & 4.6 & 22.3 & 66 & 25.0 & 4.0 & 15.9 & 17.9 \\
\hline & $11-25$ & 41 & 23.8 & 4.7 & 19.6 & 22 & 19.3 & 3.9 & 20.0 & 60 & 27.3 & 3.1 & 11.4 & 17.0 \\
\hline & $26-50$ & 39 & 24.4 & 4.1 & 16.7 & 27 & 19.5 & 4.8 & 24.5 & 51 & 27.5 & 3.5 & 12.7 & 18.0 \\
\hline & $51-75$ & 24 & 26.7 & 3.6 & 13.4 & 20 & 20.8 & 5.7 & 27.5 & 51 & 27.8 & 3.3 & 11.8 & 17.6 \\
\hline
\end{tabular}

Note: Data from Corley and Law (2001).

$\mathrm{F} / \mathrm{B}$ - fruit/bunch.

$\mathrm{M} / \mathrm{F}$ - mesocarp/fruit.

$\mathrm{DM} / \mathrm{WM}$ - dry matter content of fresh mesocarp.

$\mathrm{O} / \mathrm{DM}$ - oil/dry mesocarp.

O/WM - oil/fresh mesocarp.

$\mathrm{O} / \mathrm{B}$ - oil/bunch.

SD - standard deviations.

$\mathrm{CV}$ - coefficient of variation. 
TABLE 8. CORRELATIONS BETWEEN BUNCH COMPONENTS, INDIVIDUAL PALMS (mean of 60 correlations, with number significant at $P=0.05 / 60=0.000833$; significant positive and negative correlations shown separately)

\begin{tabular}{|c|c|c|c|c|c|c|c|c|c|}
\hline & $\mathrm{O} / \mathrm{B}$ & F/B & $\mathbf{M} / \mathbf{F}$ & DM/WM & $\mathrm{O} / \mathrm{DM}$ & O/WM & $\mathrm{K} / \mathrm{F}$ & $\mathrm{S} / \mathrm{F}$ & $\mathrm{K} / \mathrm{B}$ \\
\hline signif., +ve, -ve & 55,0 & - & 0,13 & 2,1 & 1,5 & 4,0 & 10,0 & 6,0 & 56,0 \\
\hline signif., +ve, -ve & 17,0 & - & - & 18,1 & 6,0 & 14,0 & 0,56 & 0,59 & 0,53 \\
\hline $\mathrm{DM} / \mathrm{WM}$ & 0.597 & - & - & 1 & 0.414 & 0.944 & -0.060 & -0.273 & -0.071 \\
\hline $\mathrm{O} / \mathrm{DM}$ & 0.509 & - & - & - & 1 & 0.680 & -0.007 & -0.152 & 0.038 \\
\hline signif., +ve, -ve & 44,0 & - & - & - & - & 58,0 & 0,1 & 0,11 & 3,0 \\
\hline $\mathrm{O} / \mathrm{WM}$ & 0.654 & - & - & - & - & 1 & -0.050 & -0.267 & -0.043 \\
\hline signif., +ve, -ve & 57,0 & - & - & - & - & - & 1,4 & 0,15 & 2,1 \\
\hline signif., +ve, -ve & 0,20 & - & - & - & - & - & - & - & 28,1 \\
\hline $\mathrm{K} / \mathrm{B}$ & 0.270 & - & - & - & - & - & - & - & 1 \\
\hline signif., +ve, -ve & 21,0 & - & - & - & - & - & - & - & - \\
\hline Bunch weight & 0.161 & 0.375 & -0.370 & -0.015 & 0.149 & 0.040 & 0.327 & 0.288 & 0.428 \\
\hline signif., +ve, -ve & 12,0 & 26,0 & 0,24 & 5,5 & 6,0 & 5,1 & 24,0 & 16,0 & 34,0 \\
\hline
\end{tabular}

Note: O/B - oil/bunch

$\mathrm{F} / \mathrm{B}$ - fruit/bunch

$\mathrm{M} / \mathrm{F}$ - mesocarp/fruit.

$\mathrm{DM} / \mathrm{WM}$ - dry matter content of fresh mesocarp.

$\mathrm{O} / \mathrm{DM}$ - oil/dry mesocarp.

$\mathrm{O} / \mathrm{WM}$ - oil/ fresh mesocarp.

$\mathrm{K} / \mathrm{F}$ - kernel/fruit.

$\mathrm{S} / \mathrm{F}$ - shell / fruit.

$\mathrm{K} / \mathrm{B}$ - kernel/bunch.

that $\mathrm{M} / \mathrm{F}$ is under stronger genetic control than $\mathrm{F} / \mathrm{B}$ and $\mathrm{O} / \mathrm{WM}$. K/F and $\mathrm{S} / \mathrm{F}$ were negatively correlated with $\mathrm{M} / \mathrm{F}$ in almost every palm. This is also expected, as these three components comprise $100 \%$ of fruit weight; thus if one decreases, another must increase accordingly. Kernel/bunch is also negatively correlated with $\mathrm{M} / \mathrm{F}$. Although $\mathrm{K} / \mathrm{F}$ was not correlated with $\mathrm{O} / \mathrm{B}, \mathrm{K} / \mathrm{B}$ was significantly correlated with $\mathrm{O} / \mathrm{B}$ in about one-third of palms, because both $\mathrm{O} / \mathrm{B}$ and $\mathrm{K} / \mathrm{B}$ depend partly on $\mathrm{F} / \mathrm{B}$.

In 50 out of 60 palms, $\mathrm{K} / \mathrm{F}$ was positively correlated with F/B, and M/F negatively correlated, although most of the correlations were not. A similar effect was observed after the introduction of E. kamerunicus to Malaysia: fruit set and F/B were increased, and $\mathrm{M} / \mathrm{F}$ decreased. Data from Syed et al. (1982) and Yee et al. (1985) showed an average decrease of $\mathrm{M} / \mathrm{F}$ from $78 \%$ to $75 \%$ after the introduction. In a pollination study, Hor et al. (1998) found that mean fruit weight decreased as fruit set increased; their data show that kernel weight was unchanged, so $\mathrm{K} / \mathrm{F}$ increased and $\mathrm{M} / \mathrm{F}$ decreased correspondingly.

Thus, we may conclude that much of the withinpalm variation in $\mathrm{O} / \mathrm{B}$ results from differences in fruit set and thus $\mathrm{F} / \mathrm{B}$, with increased fruit set also affecting fruit composition, and leading to lower $\mathrm{M} / \mathrm{F}$.

\section{Comparison of within and between Palm Variation}

As all bunches were analysed, we can distinguish the variation in bunch components within palms from that between palms, and thus learn more about genetic and environmental effects on bunch composition. The variation between bunches is partitioned into 'between palms' and 'between bunches within palms' components in Table 9. For F/B and oil/mesocarp within-palm variation predominates in all groups, reflecting strong environmental influence. For fruit components $(\mathrm{M} / \mathrm{F}, \mathrm{K} / \mathrm{F}$ and $\mathrm{S} / \mathrm{F})$, the between-palm component was generally larger, indicating greater genetic influence, confirming the observations in previous sections, above.

Broad-sense heritability can be estimated from the between-palms component as a fraction of total variance (Falconer, 1981) (Table 9). The mean results in Table 9 are quite similar to estimates of broad-sense heritability in the literature. These were summarised by Corley and Tinker (2016): mean broad-sense heritabilities were 0.24 for F/B, 0.66 for 
TABLE 9. VARIANCE COMPONENTS FOR BUNCH COMPOSITION

(all figures are percent of total variance)

\begin{tabular}{|c|c|c|c|c|c|c|}
\hline $\begin{array}{l}\text { Bunch } \\
\text { component }\end{array}$ & Variance Group: & $\begin{array}{l}\text { Plot A } \\
\text { duras }\end{array}$ & $\begin{array}{l}\text { Plot B } \\
\text { duras }\end{array}$ & $\begin{array}{l}\text { Plots A+B } \\
\text { teneras }\end{array}$ & $\begin{array}{l}\text { Plot C } \\
\text { teneras }\end{array}$ & $\begin{array}{l}\text { Mean of } \\
\text { all groups }\end{array}$ \\
\hline \multirow[t]{2}{*}{$\mathrm{F} / \mathrm{B}$} & Between palms & 13.4 & 21.0 & 7.7 & 33.5 & 18.9 \\
\hline & Bunches within palms & 86.6 & 79.0 & 92.3 & 66.5 & 81.1 \\
\hline \multirow[t]{2}{*}{$\mathrm{M} / \mathrm{F}$} & Between palms & 63.6 & 36.0 & 67.0 & 46.8 & 53.4 \\
\hline & Bunches within palms & 36.4 & 64.0 & 33.0 & 53.2 & 46.6 \\
\hline \multirow[t]{2}{*}{$\mathrm{DM} / \mathrm{WM}$} & Between palms & 40.8 & 16.2 & 17.8 & 12.0 & 21.7 \\
\hline & Bunches within palms & 59.2 & 83.8 & 82.2 & 88.0 & 78.3 \\
\hline \multirow[t]{2}{*}{$\mathrm{O} / \mathrm{DM}$} & Between palms & 43.4 & 28.3 & 38.4 & 34.8 & 36.2 \\
\hline & Bunches within palms & 56.6 & 71.7 & 61.6 & 65.2 & 63.8 \\
\hline \multirow[t]{2}{*}{$\mathrm{O} / \mathrm{WM}$} & Between palms & 45.1 & 18.8 & 15.3 & 18.1 & 24.3 \\
\hline & Bunches within palms & 54.8 & 81.2 & 84.7 & 81.9 & 75.7 \\
\hline \multirow[t]{2}{*}{$\mathrm{O} / \mathrm{B}$} & Between palms & 28.4 & 22.9 & 21.8 & 34.9 & 27.0 \\
\hline & Bunches within palms & 71.6 & 77.1 & 78.2 & 65.1 & 73.0 \\
\hline \multirow[t]{2}{*}{$\mathrm{K} / \mathrm{F}$} & Between palms & 67.0 & 37.7 & 74.4 & 46.2 & 56.3 \\
\hline & Bunches within palms & 33.0 & 62.3 & 25.6 & 53.8 & 43.7 \\
\hline \multirow[t]{2}{*}{$\mathrm{S} / \mathrm{F}$} & Between palms & 45.8 & 44.3 & 59.6 & 55.5 & 51.3 \\
\hline & Bunches within palms & 54.2 & 55.7 & 40.4 & 44.5 & 48.7 \\
\hline \multirow[t]{2}{*}{$\mathrm{K} / \mathrm{B}$} & Between palms & 35.7 & 33.1 & 64.0 & 44.8 & 44.4 \\
\hline & Bunches within palms & 64.3 & 66.9 & 36.0 & 55.2 & 55.6 \\
\hline \multirow[t]{2}{*}{ Bunch weight } & Between palms & 31.0 & 16.8 & 15.6 & 31.3 & 23.7 \\
\hline & Bunches within palms & 69.0 & 83.2 & 84.4 & 68.7 & 76.3 \\
\hline
\end{tabular}

Note: O/B - oil/bunch

F/B - fruit/bunch.

$\mathrm{M} / \mathrm{F}$ - mesocarp/fruit.

$\mathrm{DM} / \mathrm{WM}$ - dry matter content of fresh mesocarp.

$\mathrm{O} / \mathrm{DM}$ - oil/dry mesocarp.

O/WM - oil/fresh mesocarp.

$\mathrm{K} / \mathrm{F}$ - kernel/ fruit.

S/F - shell / fruit.

K/B - kernel/bunch.

FFB - fruih fruit bunch.

$\mathrm{M} / \mathrm{F}, 0.42$ for $\mathrm{O} / \mathrm{WM}, 0.55$ for $\mathrm{K} / \mathrm{F}$ and 0.32 for $\mathrm{O} / \mathrm{B}$. The largest difference between these values and Table 9 is for mean bunch weight, where the average figure in the literature is 0.54 , higher than in any of the groups in Table 9.

The within-palm correlations between K/B and $\mathrm{F} / \mathrm{B}$ were almost all (56 out 60 ) positive and significant (Table 8). However, large positive correlations between palm means for $\mathrm{K} / \mathrm{B}$ and $\mathrm{F} / \mathrm{B}$ were only seen in two groups (with only one significant - Table 3). For palm means in all groups and within all palms the correlations between K/F and $\mathrm{K} / \mathrm{B}$ were significant. Thus, it appears that genetic differences between palms in $\mathrm{K} / \mathrm{F}$ have a greater influence on $\mathrm{K} / \mathrm{B}$ than differences in $\mathrm{F} / \mathrm{B}$. Within palms variation in $\mathrm{F} / \mathrm{B}$ is important, both directly because $\mathrm{K} / \mathrm{B}=\mathrm{K} / \mathrm{F} \times \mathrm{F} / \mathrm{B}$, and indirectly because it can affect fruit composition, as noted above.

As both $\mathrm{O} / \mathrm{B}$ and $\mathrm{K} / \mathrm{B}$ depend partly on $\mathrm{F} / \mathrm{B}$, for 21 individual palms the correlation of $\mathrm{K} / \mathrm{B}$ and $\mathrm{O} / \mathrm{B}$ was significant (Table 8). Between palms, this correlation was not significant in any group, suggesting that it is purely a consequence of environmental differences in $\mathrm{F} / \mathrm{B}$.

Within palms, there were significant positive correlations between bunch weight and F/B (26 of 60 palms, Table 8) and negative correlations with $\mathrm{M} / \mathrm{F}$ (24 of 60 palms), but between palm means there were no significant correlations between bunch weight and either F/B or M/F. Within palms, better fruit set is likely to result in larger bunches, so a correlation between bunch weight and $\mathrm{F} / \mathrm{B}$ is expected. The negative correlation between M/F and bunch weight might result from the average negative correlation of $\mathrm{F} / \mathrm{B}$ and $\mathrm{M} / \mathrm{F}$ within palms noted above.

As noted above, palm means for $\mathrm{O} / \mathrm{DM}$ and $\mathrm{F} / \mathrm{B}$ were positively correlated (Tables 3 to 5 ), but within individual palms, the overall mean correlation was 0.01 , and was only significant for 5 of 60 palms (all positive - Table 8). F/B is strongly influenced 
by pollination efficiency, but the almost complete absence of correlations between F/B and O/DM within palms confirms that the between palms correlation is a genetic effect.

An interesting point is that within-palms S/F and $\mathrm{K} / \mathrm{F}$ were significantly correlated for 25 out of 30 teneras, with a mean value of $r=0.532$, but only for 7 out of 30 duras, with a mean of $r=0.146$. The difference in mean $r$ was highly significant (after transformation of $r$ to $z$, where $z=0.5\left[\left(\log _{\mathrm{e}}(1+\mathrm{r})\right.\right.$ - $\left.\log _{\mathrm{e}}(1-r)\right]$; Snedecor and Cochran, 1966). Between palms, K/F and S / F were correlated in both groups of teneras and in Plot Aduras, but not in Plot B duras. A positive correlation between $\mathrm{K} / \mathrm{F}$ and $\mathrm{S} / \mathrm{F}$ might be expected, as larger kernels should need more shell to enclose them; between palms, Jeenor and Volkaert (2014) and Seng et al. (2016) both found significant correlations in tenera progenies, and there was a correlation of 0.67 in the 955 palms mentioned above (Teh, C K, pers. comm., 2017). Corley and Tinker (2016) noted that, if shell thickness in $\mathrm{mm}$ remains the same, an increase in kernel size will have a greater relative effect on $\mathrm{S} / \mathrm{F}$ in teneras than in duras, though the difference appears to be small. Van der Vossen (1974) considered that variation in kernel size led to parallel changes in S/F in teneras, but less so in duras where lignification of the 'potential shell' region is complete. The results here suggest that this may be so when kernel size is affected by environment (within-palm variation in fruit set), in addition to the genetic variation between palms studied by van der Vossen (1974). To understand this better, actual weights rather than percentages should be studied.

\section{CONCLUSION}

Detailed information on within-palm variation has not been available previously. F/ B is the most variable component, followed by oil/mesocarp; for both of these components, variation between bunches within palms is greater than betweenpalm variation. $\mathrm{F} / \mathrm{B}$ affects both oil and $\mathrm{K} / \mathrm{B}$, but it also appears to affect $\mathrm{M} / \mathrm{F}$; a similar negative effect of increased $\mathrm{F} / \mathrm{B}$ on $\mathrm{M} / \mathrm{F}$ has been recorded in pollination studies.

There have been several generations of breeding since these plots were planted, and it could be argued that the results are no longer relevant. Breeders have placed some emphasis on increasing uniformity, so palm-to-palm variation in commercial plantings may be lower now than in 1960s material. However, little consideration has been given to reducing bunch-to-bunch variability within palms, so it is likely that withinpalm variation is little changed from the 1960s. The consequences of within-palm variability for bunch sampling and O/B and oil yield estimates are considered by Corley (2018).

Only tentative conclusions on betweenpalm variation can be drawn from these small, unrelated groups of palms, but there are several previously unrecorded correlations between bunch components. A correlation between palm means for $\mathrm{F} / \mathrm{B}$ and $\mathrm{O} / \mathrm{DM}$ was found, which is supported by some observations from other authors. As shown by Corley (2018), the precision of bunch component estimates based on only a few bunches is poor, and it may be that these correlations will only be detected when bunch analysis is done in the detail described here.

\section{ACKNOWLEDGEMENT}

The bunch analysis project was part of the programme of the Oil Palm Genetics Laboratory, jointly funded in the 1960s and early 1970s by Unilever Plantations, Kumpulan Guthrie, Harrisons and Crosfield and Dunlop Estates.

\section{ABBREVIATION}

\begin{tabular}{|c|c|}
\hline CV & Coefficient of variation \\
\hline d.f. & Degrees of freedom \\
\hline $\mathrm{DM} / \mathrm{WM}$ & $\begin{array}{l}\text { Dry matter content of fresh } \\
\text { mesocarp }(\%)\end{array}$ \\
\hline $\mathrm{DxP}$ & Dura $\times$ pisifera \\
\hline $\mathrm{F} / \mathrm{B}$ & Fruit/bunch $(\%)$ \\
\hline FFB & Fresh fruit bunch \\
\hline $\mathrm{K} / \mathrm{B}$ & Kernel/bunch (\%) \\
\hline $\mathrm{K} / \mathrm{F}$ & Kernel/fruit (\%) \\
\hline $\mathrm{M} / \mathrm{F}$ & Mesocarp / fruit $(\%)$ \\
\hline NIFOR & $\begin{array}{l}\text { Nigerian Institute for Oil Palm } \\
\text { Research }\end{array}$ \\
\hline $\mathrm{O} / \mathrm{B}$ & Oil/bunch $(\%)$ \\
\hline $\mathrm{O} / \mathrm{DM}$ & Oil/dry mesocarp (\%) \\
\hline $\mathrm{O} / \mathrm{WM}$ & Oil/fresh mesocarp (\%) \\
\hline $\mathrm{P}$ & Probability \\
\hline QTL & Quantitative trait linkage \\
\hline $\mathrm{r}$ & Correlation coefficient \\
\hline & Standard deviations \\
\hline$S / F$ & Shell/fruit $(\%)$ \\
\hline & $0.5\left[\log _{\mathrm{e}}(1+\mathrm{r})-\log _{\mathrm{e}}(1-\mathrm{r})\right]$ \\
\hline
\end{tabular}

\section{REFERENCES}

BLAAK, G; SPARNAAIJ, L D and MENENDEZ, $\mathrm{T}$ (1963). Breeding and inheritance in the oil palm (Elaeis guineensis Jacq.) Part II. Methods of bunch quality analysis. J. W. Afr. Inst. Oil Palm Res. 4: 146155.

BONFERRONI, CE (1936). Teoria statistica delle classi e calcolo delle probabilita. Libreria internazionale Seeber. 
BREURE, C J and CORLEY, R H V (1992). Fruiting activity, growth and yield of oil palm. II. Observations in untreated populations. Expl Agric., 28: 111-121.

CHAN, K S; SOH, A C and CHEW, P S (1999). An accurate and precise method of determining oil to bunch in oil palm. J. Oil Palm Res. Vol. 11: 11-22.

CORLEY, R H V (1977). Oil palm yield components and yield cycles. International Developments in Oil Palm (Earp, D A and Newall, W eds.). Incorporated Society of Planters, Kuala Lumpur. p. 116-129.

CORLEY, R H V (2005). Illegitimacy in oil palm breeding - A review. J. Oil Palm Res. Vol. 17: 64-69.

CORLEY, R H V (2018). Studies of bunch analysis: 2 - Bunch sampling to estimate oil yield. J. Oil Palm Res. Vol. 30(2): 206-218. DOI: https://doi. org/10.21894/jopr.2018.0019.

CORLEY, R H V and LAW, I H (2001). Ripening, harvesting and oil extraction. The Planter, 77: 507524.

CORLEY, R H V and TINKER, P B (2016). The Oil Palm. Wiley Blackwell, Oxford.

FALCONER, D S (1981). Introduction to Quantitative Genetics. Longman, London \& New York.

HOR, T Y; SOH, A C; CHAN, K S; CHEW, P S and $\mathrm{GOH}, \mathrm{K} J$ (1998). Studies on oil palm bunch characteristics effects on oil extraction ratio. Proc. of the 1996 International Conference on Oil and Kernel Production in Oil Palm - A Global Perspective (Rajanaidu, N; Henson, I E and Jalani, B S eds.). PORIM, Bangi. p. 229-255.

JEENNOR, S and VOLKAERT, H (2014). Mapping of quantitative trait loci (QTLs) for oil yield using SSRs and gene-based markers in African oil palm (Elaeis guineensis Jacq.). Tree Genetics E Genomes, 10: 1-14.
LIM, K H and TOH, P Y (1985). The accuracy and precision of bunch analysis. Proc. of the Symp. Impact of the Pollinating Weevil on the Malaysian Oil Palm Industry. PORIM, Bangi. p. 91-109.

RAO, V; SOH, A C; CORLEY, R H V; LEE, C H; RAJANAIDU, N; TAN, Y P; CHIN, C W; LIM, K C; TAN, S T; LEE, T P and NGUI, M (1983). A critical reexamination of the method of bunch quality analysis in oil palm breeding. PORIM Occasional Paper, 9: 1-28.

SENG, T Y; RITTER, E; SITI HAWA, M S; LEAO, L J; RAJINDER, S; FARIDAH, Q Z; TAN, S G; SHARIFAH, S R S A and RAO, V (2016). QTLs for oil yield components in an elite oil palm (Elaeis guineensis) cross. Euphytica, 212: 399-425.

SHARMA, M; GURMIT, S; TOH, T S and SINGH, T (1999). Optimising on FFB, oil, OER and oil quality. Paper presented at the 1999 PORIM International Palm Oil Congress. Kuala Lumpur.

SNEDECOR G W and COCHRAN, WG (1966). Statistical Methods. Iowa State University press, Ames, Iowa, USA.

SYED, R A; LAW, I H and CORLEY, R H V (1982). Insect pollination of oil palm: Introduction, establishment and pollinating efficiency of Elaeidobius kamerunicus in Malaysia. The Planter, 58: 547-561.

VAN DER VOSSEN, HAM (1974). Towards More Efficient Selection for Oil Yield in the Oil Palm (Elaeis guineensis Jacquin). Thesis, Wageningen University.

YEE, C B; LIM, K C; ONG, E C and CHAN, K W (1985). The effects of E. kamerunicus on bunch components of E. guineensis. Proc. of the Symp. Impact of the Pollinating Weevil on the Malaysian Oil Palm Industry. PORIM, Bangi. p. 129-139. 